\title{
Tetrahydrocarbazole Derivatives as Corrosion Inhibitors for Zinc in $\mathrm{HCl}$ Solution
}

\author{
A.S. Fouda(Corresponding author) \\ Department of Chemistry, Faculty of Science, El-Mansoura University, El-Mansoura-35516, EGYPT
}

Tel: 2-050-236-5730 fax: 2-050-224-6781Ｅ-mail: asfouda@mans.edu.eg

M. Abdallah \& S.T.Atwa

Department of Chemistry, Faculty of Science, Benha University, Benha, EGYPT

\author{
M.M.Salem \\ Department of Chemistry, Faculty of Science, El-Mansoura University, El-Mansoura-35516, EGYPT
}

\begin{abstract}
The inhibition of the corrosion of zinc in $0.4 \quad \mathrm{M} \quad \mathrm{HCl}$ by (Z)-2-(2-(4-methoxyphenyl)hydrazono)-3-(5,6,7,8-tetrahydrocarbazol-9-yl)-3-oxopropanenitrile(1),(Z)-2-(2-(4-c hlorophenyl)hydrazono)-3-(5,6,7,8-tetrahydrocarbazol-9-yl)-3-oxopropanenitrile(2),(Z)-2-(2-phenylhydrazono)3-(5,6,7,8-tetrahydrocarbazol-9-yl)-3-oxopropanenitrile(3)and

(Z)-2-(2-(4-nitrophenyl)hydrazono)-3-(5,6,7,8-tetra hydrocarbazol-9-yl)-3-oxopropanenitrile (4) has been investigated at $30{ }^{\circ} \mathrm{C}$ using weight loss, potentiodynamic polarization, electrochemical impedance spectroscopy (EIS) and electrochemical frequency modulation (EFM) measurements. Results obtained show that these investigated compounds are good inhibitors and their inhibition efficiencies (IE \%) increase with the increase of inhibitor concentration and with rise of temperature. Moreover, polarization studies clearly reveal that the presence of inhibitors changes the mechanism of hydrogen evolution and that they act as mixed inhibitors. EIS study shows that charge transfer resistance increases with the inhibitor concentration. The adsorption of investigated compounds obeys Langmuir's adsorption isotherm. Effect of temperature is studied between 30 and $50{ }^{\circ} \mathrm{C}$ and determination of activation parameters is also discussed. The mechanism of adsorption had been explained on the basis of chemical structure of the investigated inhibitors. It was found that there is a good agreement between the different tested techniques.
\end{abstract}

Keywords: Corrosion inhibition, HCl, Zinc, EIS and EFM techniques, Tetrahydrocarbazole derivatives

\section{Introduction}

Acid solutions are widely used in industry. Zinc is a metal with numerous industrial applications and is mainly used for the corrosion protection of steel (Manov, 1999). Zinc is an industrially important metal and is corroded by many agents, of which aqueous acids are the most dangerous (Gaur and Jain, 1978).

Looking at its increasing use, the study of corrosion inhibition is of paramount importance. The dissolution behavior of zinc in acidic and nearly neutral media is known to be inhibited by nitrogen and sulfur-containing organic compounds. Such compounds contain electron-donating groups that decrease the corrosion rate by increasing the hydrogen overvoltage on the corroding metal (Gad Allah et al., 1989). Hydrochloric acid is one of the most widely applied aqueous mineral acids in industry. The removal of oxide from metallic parts before applying coatings, oil well acidizing, industrial acid cleaning, acid descaling and acid pickling are some of the important fields of $\mathrm{HCl}$ applications. The highly corrosive nature of this acid on most metals and alloys requires some degree of restraint to achieve economic maintenance and operation of the equipment, minimize the loss of chemical products and minimize safety. The use of inhibitors is one of metals and alloys, especially in acidic media.

Studies of the effect of organic additives on the corrosion rate of zinc had been the subject of many investigators (Abdel Aal, 1983; Nielsen, 1996 ; Ravindran et al.,1995; Rajappa et al., 2001; Maja et al., 1993; Huang et al., 1997; Kampalappa et al., 2003; Ein-Eli et al., 2003; Venckatesh et al., 2007). Most organic inhibitors are substances with at least one functional group that considered being a reaction centre for the adsorption of the compound on the corroding surface, therefore forming barrier to its direct contact with corrosive environment. Nitrogen-containing compounds are commonly applied as corrosion inhibitors with $\mathrm{HCl}$. Efficiency of aldehyde and amino acids as inhibitors of corrosion for different metals in different corrosive environments had been studied by several workers 
(Aksut and Onal, 1995); Selim 1997; Salghi et al., 2000) and their inhibition efficiency is due to the formation of a protective layer or film on the metallic surface. The effect of some ethoxylated fatty alcohols, with different numbers of ethylene oxide units, on the corrosion of $\mathrm{Zn}$ in $0.5 \mathrm{M} \mathrm{HCl}$ had been studied (Abdallah, 2003). Amidopoly ethylamines are used as corrosion inhibitors for zinc in $\mathrm{ZnCl}_{2}, \mathrm{NH}_{4} \mathrm{Cl}$ and in mixture of both ( $\mathrm{Abdallah}$, 2009 ).

The major objective of the present work was to study the effect of tetrahydrocarbazole derivatives as corrosion inhibitors for $\mathrm{Zn}$ in $0.4 \mathrm{M} \mathrm{HCl}$ solution.

\section{Experimental details}

\subsection{Materials and reagents}

Zinc strips (BDH grade) containing: $0.002 \% \mathrm{Fe}, 0.001 \% \mathrm{~Pb}, 0.003 \% \mathrm{Cu}, 0.001 \% \mathrm{Cd}$, and rest $\mathrm{Zn}$ were used in this investigation. All chemicals used were of AR grade. Specimens of zinc strips were abraded successively by emery papers of different grades, i.e. 150,320, 400 and 600, and finally polished with a 4/0 emery paper to obtain mirror like finish. Then degreased ultrasonically with ethyl alcohol and rinsed with bidistilled water several times and dried between two fitter papers. AR grade hydrochloric acid (37\%) was used for preparing the corrosive solutions. Appropriate concentration of aggressive solutions used $(0.4 \mathrm{M} \mathrm{HCl})$ was prepared using bidistilled water .The tetrahydrocarbazole derivatives were synthesized in the laboratory using standard procedure (Etman et al., 2009). It was purified and characterized by IR spectroscopy and other standard techniques before use. The following derivatives of tetrahydrocarbazole were studied,

Names, molecular formulae, structures and molecular weights of the investigated tetrahydrocarbazole derivatives are:

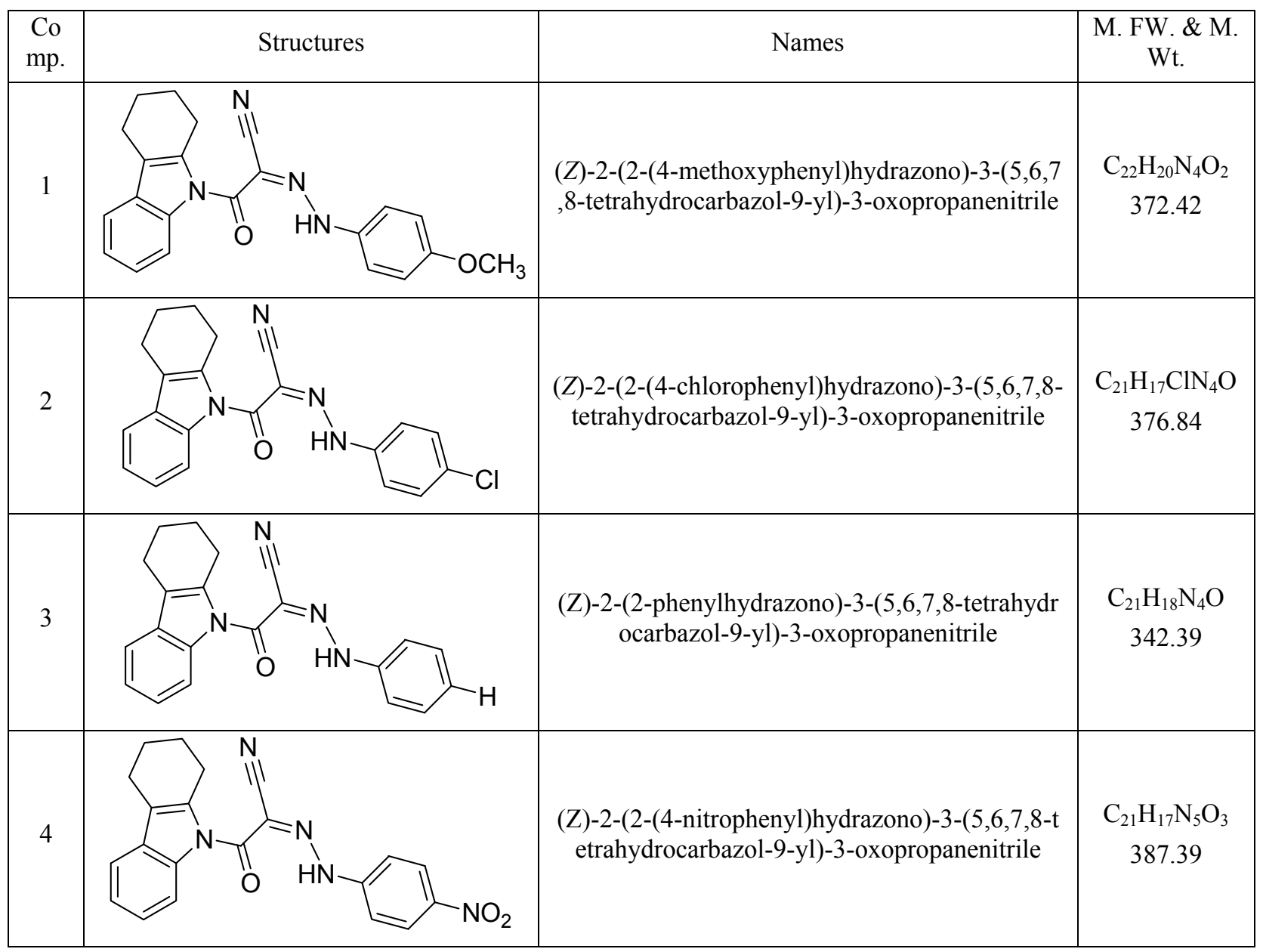




\subsection{Measurements}

\subsubsection{Weight loss measurements}

For weight loss measurements, rectangular zinc specimens of size $20 \times 20 \times 2 \mathrm{~mm}$ were immersed in $50 \mathrm{ml}$ inhibited and uninhibited solutions and allow to stand for several intervals at $30 \pm 1^{\circ} \mathrm{C}$ in water thermostat. Therefore, the weight losses given by:

$$
\Delta \mathrm{m}=\left(\mathrm{m}_{1}-\mathrm{m}_{2}\right)
$$

where $\mathrm{m}_{1}$ and $\mathrm{m}_{2}$ are the weights of metal before and after exposure to the corrosive solution, respectively. The percentage inhibition efficiency (IE \%) and the degree of surface coverage $(\theta)$ of the investigated compounds was calculated from the following equations:

$$
\begin{aligned}
\mathrm{IE} \% & =\left[1-\left(\Delta \mathrm{m}_{\text {inh }} / \Delta \mathrm{m}_{\text {free }}\right)\right] \times 100 \\
\theta & =\left[1-\left(\Delta \mathrm{m}_{\text {inh }} / \Delta \mathrm{m}_{\text {free }}\right)\right]
\end{aligned}
$$

where $\Delta \mathrm{m}_{\text {free }}$ and $\Delta \mathrm{m}$ inh are the weight losses per unit area in the absence and presence of additives, respectively.

\subsubsection{Electrochemical measurements}

A three electrode electrochemical cell was used. The working electrode was zinc with $1 \mathrm{~cm}$ long cylindrical $\mathrm{Zn}$ electrode $(\varphi=5 \mathrm{~mm})$. Before each experiment, the electrode was abraded using emery paper as before. After this, the electrode was cleaned ultrasonically with ethyl alcohol and washed by bidistilled water. All potentials were given with reference to the saturated calomel electrode (SCE). The counter electrode was a platinum plate of surface area of $1 \mathrm{~cm}^{2}$. The working electrode was immersed in the test solution during 30 min until a steady state open circuit potential $\left(\mathrm{E}_{\text {ocp }}\right)$ was obtained. The polarization curves were recorded by polarization from $-0.4 \mathrm{~V}$ to $-1.6 \mathrm{~V}$ under potentiodynamic conditions corresponding to $1 \mathrm{mV} / \mathrm{s}$ (sweep rate) and under air atmosphere. All measurements were carried out with zinc electrode in $0.4 \mathrm{M} \mathrm{HCl}$ in the absence and presence of different concentrations $\left(1 \times 10^{-6}-21 \times 10^{-6} \mathrm{M}\right)$ of the investigated inhibitors at $30^{\circ} \mathrm{C}$. All experiments were carried out at $30 \pm 1^{\circ} \mathrm{C}$. The inhibition efficiency and surface coverage $(\theta)$ were calculated from the following equations:

$$
\begin{aligned}
\% \mathrm{IE} & =\left[1-\left(\mathrm{j}_{\text {corr. (inh.) }} / \mathrm{j}_{\text {corr. (rree) })}\right)\right] \times 100 \\
\theta & =\left[1-\left(\mathrm{j}_{\text {corr. (inh.) }} / \mathrm{j}_{\text {corr(free })}\right)\right]
\end{aligned}
$$

where $\mathrm{j}_{\text {corr(free) }}$ and $\mathrm{j}_{\text {corr(inh) }}$ are the corrosion current densities in the absence and presence of inhibitor, respectively.

Electrochemical impedance spectroscopy measurements were performed using the same cell that used in polarization experiments. The EIS carried out over a frequency range of $1 \mathrm{kHz}$ to $1 \mathrm{~Hz}$, with a signal amplitude perturbation of $10 \mathrm{mV}$. Nyquist plots were obtained from the results of these experiments. Values of the charge transfer resistance $\left(R_{\mathrm{ct}}\right)$ were obtained from these plots by determining the difference in the values of impedance at low and high frequencies, as suggested by (Tsuru et al, 1978) Values of the double layer capacitance $\left(C_{\mathrm{dl}}\right)$ were calculated from the relation:

$$
\mathrm{C}_{\mathrm{dl}}=\frac{1}{2 \pi \mathrm{f}_{\max } \mathrm{R}_{\mathrm{ct}}}
$$

Where, $f_{\max }$ is the frequency at which the imaginary part $\left(Z_{\text {imag. }}\right)$ of the impedance is a maximum. The inhibition efficiency (IE \%) and surface coverage $(\theta)$ of the investigated compounds obtained was calculated from the following equations:

$$
\begin{aligned}
\% \mathrm{IE} & =\left[\left(\mathrm{R}_{\mathrm{ct}}-\mathrm{R}_{\mathrm{ct}}^{\circ}\right) / \mathrm{R}_{\mathrm{ct}}\right] \times 100 \\
\theta & =\left[\left(\mathrm{R}_{\mathrm{ct}}-\mathrm{R}_{\mathrm{ct}}^{\mathrm{o}}\right) / \mathrm{R}_{\mathrm{ct}}\right]
\end{aligned}
$$

where $R^{o}$ and $R_{c t}$ are the charge transfer resistance values in the absence and presence of the inhibitors, respectively.

Electrochemical frequency modulation is a non destructive technique as electrochemical impedance spectroscopy that can directly and rapidly give values of the corrosion current without a prior knowledge of Tafel constants.The great of the EFM is the causality factors, which serves as an internal check on the validity of the EFM measurement .With the causality factors the experimental EFM data can be verified (Bosch et al., 2001, Abdel- Rehim et al., 2006). Identical cell assembly was used as in impedance studies. All electrochemical measurements (potentiodynamic, impedance and EFM) were carried out using Potentiostat /Galvanostat / Zra analyzer (Gamry PCI300/4).A personal computer with de 105 software for potentiodynamic, EIS 300 software and 140 software for EMF and Echem Analyst 5.21 was used for data fitting. 


\section{Results and Discussion}

\subsection{Weight-loss measurements}

Fig 1 shows the effect of increasing concentrations of compound 1 on the weight loss of $\mathrm{Zn}$ vs. time curves at $30^{\circ} \mathrm{C}$. Similar curves (not shown) were obtained for the other three compounds. It is obvious that the weight loss of $\mathrm{Zn}$ in presence of inhibitors varies linearly with time, and is much lower than that obtained in blank solution. The linearity obtained indicated the absence of insoluble surface film during corrosion and that the inhibitors were first adsorbed onto the metal surface and, therefore, impede the corrosion process (Abdallah, 2004). The calculated values of the percentage inhibition efficiency (I \%) are listed in Table 1. Inspection of Table 1 reveals that, the inhibition efficiency increases with an increase in inhibitor concentration. This behavior could be attributed to the increase of the number of adsorbed molecules at the metal surface. At one and the same inhibitors concentration I \% decreases in the following order: $(1)>(2)>(3)>(4)$

\subsection{Adsorption isotherm}

Basic information on the interaction between the inhibitors and the $\mathrm{Zn}$ can be provided by the adsorption isotherm. Two main types of interaction can describe the adsorption of the organic compound: physical adsorption and chemical adsorption. These are influenced by the chemical structure of the inhibitor, the type of the electrolyte, the charge and nature of the metal. The surface coverage, $\theta$, of the metal surface by the adsorbed inhibitor was evaluated from weight loss measurements using equation 3 . The $\theta$ values of different inhibitor concentrations at $30{ }^{\circ} \mathrm{C}$ were tested by fitting to various isotherms including, Frumkin, Langmuir, Temkin and Flory-Huggins. By far the best fit was obtained with the Langmuir isotherm. A plot $(\mathrm{C} / \theta)$ against $\mathrm{C}$, for all concentrations of inhibitors (Fig 2) a straight line relationship was obtained in all cases with a correlation coefficients $\left(\mathrm{R}^{2}\right)$ in the range $0.998>$ $\mathrm{R}^{2}>0.994$. Also, the kinetic-thermodynamic model of (El- Awady et al., 1985) with the formula:

$$
\log (\theta / 1-\theta)=\log \mathrm{K}^{\prime}+\mathrm{y} \log \mathrm{C}
$$

is valid and verify the present adsorption data (Fig 3). The equilibrium constant of adsorption $\quad K=K^{\prime}(1 / y)$, where $1 / \mathrm{y}$ is the number of the surface active sites occupied by one inhibitor molecule and $\mathrm{C}$ is the bulk concentration of the inhibitor. The negative $\Delta \mathrm{G}^{\circ}$ ads values (Table 2) are consistent with the spontaneity of the adsorption process and the stability of the adsorbed layer on the Zn surface (Popova et al., 2003).

It generally accepted that the values of $\Delta \mathrm{G}_{\text {ads }}^{\circ}$ up to $-20 \mathrm{~kJ} \mathrm{~mol}^{-1}$ the types of adsorption were regarded as physisorption, the inhibition acts due to the electrostatic interaction between the charged molecules and the charged metal, while the values around $-40 \mathrm{~kJ} \mathrm{~mol}^{-1}$ or smaller, were seen as chemisorptions, which is due to the charge sharing or a transfer from the inhibitor molecules to the metal surface to form covalent bond (Szlarska-Smialowska et al, 1978, Yurt et al, 2006). The $\Delta \mathrm{G}^{\circ}$ ads values obtained in this study range from - 40.4 to $42.7 \mathrm{~kJ} \mathrm{~mol}^{-1}$. It suggested that the adsorption mechanism of investigated inhibitors on $\mathrm{Zn}$ in $0.4 \mathrm{M} \mathrm{HCl}$ solution was typical of chemisorptions.

\subsection{Kinetic-thermodynamic corrosion parameters}

As noticed previously, the adsorption process was well elucidating by using a thermodynamic model, in addition a kinetic-thermodynamic model was another tool to explain the mechanism of corrosion inhibition for an inhibitor. The apparent effective activation energies $\left(\mathrm{E}_{\mathrm{a}}^{*}\right)$ for the corrosion reaction of $\mathrm{Zn}$ in $\mathrm{HCl}$ in the absence and presence of different concentrations of investigated compounds were calculated from Arrhenius-type equation (Bochris and Reddy 1970):

$$
\mathrm{k}=\mathrm{A} \exp \left(-\mathrm{E}_{\mathrm{a}}^{*} / \mathrm{RT}\right)
$$

where $\mathrm{A}$ is the Arrhenius pre-exponential factor. A plot of $\log \mathrm{k}$ (corrosion rate) vs. 1 / $\mathrm{T}$ gave straight lines as shown in Fig.2. The entropy of activation $\left(\Delta \mathrm{S}^{*}\right)$ and the enthalpy of activation $\left(\Delta \mathrm{H}^{*}\right)$ for the intermediate complex in the transition state for the corrosion of $\mathrm{Zn}$ in $\mathrm{HCl}$ in the absence and presence of different concentrations of investigated compounds were obtained by applying the transition-state equation (Martinez and Stern 2002; Tebbji et al., 2007; Mihit et al.,2006)

$$
\mathrm{k}=\mathrm{RT} / \mathrm{Nh} \exp \left(\Delta \mathrm{S}^{*} / \mathrm{R}\right) \exp \left(-\Delta \mathrm{H}^{*} / \mathrm{RT}\right)
$$

where $\mathrm{h}$ is the Planck's constant and $\mathrm{N}$ is the Avogadro's number

A plot of $\log \mathrm{k}$ (corrosion rate) / T vs. 1 / T should give a straight lines (Fig.3), with a slope of (- $\Delta \mathrm{H}^{*} / 2.303 \mathrm{R}$ ), and an intercept of $\left[\left(\log (\mathrm{RT} / \mathrm{Nh})+\left(\Delta \mathrm{S}^{*} / 2.303 \mathrm{R}\right)\right]\right.$ (Bouklah et al., 2006; Bouklah et al., 2006), from which the values of $\Delta \mathrm{H}^{*}$ and $\Delta \mathrm{S}^{*}$ were calculated, respectively. Table (3) exhibited values of apparent activation energy, apparent enthalpies $\Delta \mathrm{H}^{*}$ and entropies $\Delta \mathrm{S}^{*}$ for $\mathrm{Zn}$ dissolution in $0.4 \mathrm{M} \mathrm{HCl}$ solution in the absence and presence of different 
investigated compounds. The presence of tetrahydrocarbazole derivatives decreased the activation energies of $\mathrm{Zn}$ indicating strong adsorption of the inhibitor molecules on the metal surface and the presence of these additives induces chemical bonds with $\mathrm{Zn}$ surface. These chemical bonds increased with increase of the additive concentrations. Values of the entropy of activation $\Delta \mathrm{S}^{*}$ in the absence and in presence of the studied compounds are negative. This implies that the activated complex in the rate determining step represents an association rather than a dissociation step (AbdEl-Rehim et al., 1999). This means that the activated molecules were in higher order state than that at the initial stage (Abdallah, 2003; Fouda et al., 2006).

\subsection{Electrochemical measurement}

Fig. (4) showed the potentiodynamic polarization curves for zinc in $0.4 \mathrm{M} \mathrm{HCl}$ solution in the absence and presence of different concentrations of compound (1). The effect of increased concentration were studied for all compounds, revealed that the presence of increase of the concentration of inhibitor caused a decrease in the corrosion rate . The corrosion current density $\left(\mathrm{j}_{\text {corr }}\right)$ was calculated by the extrapolation of anodic and cathodic Tafel lines. Table (4) showed that increase of the concentration of compound decreased the corrosion current density and shifts the corrosion potential to more negative values .Both anodic and cathodic Tafel slopes decreased by the addition of compound.

The $\%$ inhibition increased with increasing the concentration of the compounds, the inhibition efficiency of the four tested compounds measured by polarization method decreased in the following order: $(1)>(2)>(3)>(4)$. This sequence is in accordance with that obtained from weight-loss measurements.

\subsection{Electrochemical impedance spectroscopy}

Figures (5\& 6) showed the Nyquist and Bode plots for $\mathrm{Zn}$ metal in $0.4 \mathrm{M} \mathrm{HCl}$ solution in the absence and presence of different concentrations of compound (1). The impedance response consisted of characteristic semicircles for all solutions examined indicating that the dissolution process occurs under charge transfer control and the presence of the additive compound did not alter the mechanism of the acid dissolution. The impedance spectra for different Nyquist and Bode plots were analyzed by fitting the experimental spectra data to a simple equivalent circuit model, Fig. (7), which includes the solution resistance $\left(R_{s}\right)$ and the double layer capacitance $\left(C_{\mathrm{dl}}\right)$ which is placed in parallel to charge transfer resistance element, $\left(R_{c t}\right)$. Values of $R_{c t}$ and $C_{d l}$ for $\mathrm{Zn}$ in $0.4 \mathrm{M} \mathrm{HCl}$ containing different concentration of compound (1) and the inhibition efficiencies are given in Table (5). In an activated controlled system, the corrosion current density was calculated using the Stern-Geary equation (Stern and Geary, 1957):

$$
\mathrm{j}_{\text {corr }}=\left[\left(\beta_{\mathrm{a}} \beta_{\mathrm{b}}\right) / 2.303\left(\beta_{\mathrm{a}}+\beta_{\mathrm{b}}\right) \mathrm{R}_{\mathrm{ct}}\right]
$$

The cathodic and anodic Tafel slopes $\beta_{\mathrm{a}}$ and $\beta_{\mathrm{c}}$ were calculated from the corresponding polarization curves. From the impedance data given in Table (5), we conclude that:

1) As the impedance diagram obtained has a semicircle appearance, it shows that the corrosion of $\mathrm{Zn}$ is mainly controlled by a charge transfer process.

2) The value of $R_{c t}$ increased with increase of the concentration of the inhibitors and this indicated the increase in the corrosion inhibition efficiency in acidic solution.

3) The value of double layer capacitance decreased by increasing the inhibitor concentration. This is due to the adsorption of these compounds on the electrode surface leading to a film formation on the $\mathrm{Zn}$ surface. The order of inhibition efficiency obtained from EIS measurements is as follows: $(1)>(2)>(3)>(4)$

This sequence is in accordance with that obtained from weight-loss and polarization measurements.

\subsection{Electrochemical Frequency Modulation Technique (EFM)}

Results of EFM experiments is a spectrum of current response as function of frequency. The spectrum is called the "inter modulation spectrum" and an example was shown in Figures.8-12. However, Figures.8-12 showed the corresponding current response in the inter modulation spectrum .The harmonic and inter modulation peaks are clearly visible and are much larger than background noise. The two large peaks, with amplitudes of about $200 \mu \mathrm{A}$, are the response to the 2 and $5 \mathrm{~Hz}$ excitation frequencies. Those peaks between 1 and $20 \mu \mathrm{A}$ are the harmonic, sums, and differences of the two excitation frequencies. Analysis of these peaks at inter modulation frequencies can reveal the corrosion rate and Tafel parameters. It is important to note that between the peaks the current response is very small .The corrosion parameters such as inhibition efficiency $(\% \mathrm{IE})$, corrosion current density $\left(\mu \mathrm{A} / \mathrm{cm}^{2}\right)$, Tafel constants and causality factors, at different concentrations of additive compounds in $0.4 \mathrm{M} \mathrm{HCl}$ solution at $30{ }^{\circ} \mathrm{C}$ are presented in Table (6). Table (6) The corrosion current densities decreased by increasing the concentration of compound (1). The causality factors in Table (6) indicated that the measured data are of good quality . The standard values for CF-2 and CF-3 are 2 and 3, respectively. The causality factor is calculated from 
the frequency spectrum of the current response. If the causality factors are approximately equal to the predicted values of 2 and 3, there is a causal relationship between the perturbation signal and the response signal .Then the data are assumed to be reliable (Bosch et al., 2001). When CF-2 and CF-3 are in the range 0-2 and 0-3, respectively, then the EFM data is valid. The deviation of causality factors from their ideal values might due to that the perturbation amplitude was too small or that the resolution of the frequency spectrum is not high enough also another possible explanation that the inhibitor is not performing very well (Abdel-Rehim et al., 2006).

\section{Conclusions}

1) The used new biologically active tetrahydrocarbazole derivatives as corrosion inhibitors for zinc in $0.4 \mathrm{M} \mathrm{HCl}$ act as an efficient inhibitor.

2) The inhibition efficiency increases with the increase of inhibitor concentration and with rising of temperature.

3) The data obtained from all different techniques namely weight loss, potentiodynamic polarization, electrochemical impedance spectroscopy and electrochemical frequency modulation is in good agreement.

4) Adsorption of tetrahydrocarbazole derivatives on the $\mathrm{Zn}$ surface from acidic solution followed Langmuir isotherm, indicating that the main inhibition process occurred via adsorption.

5) The activation parameters $\mathrm{E}_{\mathrm{a}}{ }^{*}, \Delta \mathrm{H}^{*}$ and $\Delta \mathrm{S}^{*}$ for the corrosion of $\mathrm{Zn}$ in $\mathrm{HCl}$ solution containing inhibitors are presented.

\section{References}

Abdallah, M. (2004). Corros.Sci. 46, 1981.

Abdallah M. (2003). Corros. Sci., 45, 2705.

Abdallah M., El-Etre A.Y., and.Mostafa M.F. (2009). Port.Electrochim.Acta, 27(5), 615

Abdel Aal M. S., Radwan S., and El-Saied A. (1983). Br. Corros. J, 18, 102

Abd El-Naby, B.A., El-Tokhy, A., El-Gamal, M and Mahgoub, F. (1986). Surf.and Coat.Technol., 27, 325.

Abdel- Rehim S .S., Khaled K.F., Abd-Elshafi N.S. (2006). Electrochim .Acta 51, 3269.

Abdel- Rehim S .S., Ibrahim M.A., Khaled K.F. (2001). Mater.Chem.Phys., 70, 268.

AbdEl-Rehim S.S., IbrahimM.A.M, KhaledK.F. (1999). J.Appl.Electrochem. 29,593.

AbdEl-Rehim S.S., IbrahimM.A.M, KhaledK.F. (2001). Mater.Chem.Phys., 70, 268.

Abdel-Rehim S. S., Khaled K.F., Abd-Elshafi N. S. (2006). Electrochim. Acta, 51, 3269.

Aksut A.A, and Onal A.N. (1995). Bull. Electrochem. 11, 513.

Antropov,L.I. (1967). Corros. Sci., 7,607.

Bech - Nielsen. (1996). Corros.Sci., 38, 1385.

Bochris J.O’M., Reddy A.K .N. (1970). Modern Electrochemistry, Plenum Press, New York,.

Bosch R. W., Hubrecht J., Bogaerts W. F., Syrett B. C. (2001). Corrosion, 57, 60.

Bouklah M.,Hammouti B.,Lagrenee M.,Bentiss F. (2006). Corros.Sci., 48,2831.

Bouklah M., Benchat N., Hammouti B., Aouniti A., Kertit S. (2006). Mater. Lett. 60, 1901.

Cao, C.N. (2004). Corrosion Electrochemistry Mechanism, Chemical Engineering Press, Beijing, p.235 (in Chinese).

Ein-Eli Y. ,Auinat M. ,Starosvetsky D. (2003). J. Power Sources, 114,330.

El- Awady Y.A., and Ahmed A.I. (1985). J. Ind. Chem., 24A, 601.

Etman H.A , Sarhan A .A. , El-Hadidy Sh .A. (2009). M.Sc.Thesis, Mansoura University, Egypt.

Fouda A.S., Al-Sarawy A.A. and El-Katori E.E. (2006). Desalination, 201, 1.

Fouda A.S.,.Moussa M.M, Taha F.I.and A.I.El-Neanaa. (1986). Corros.Sci., $26,719$.

Gad Allah A.G., Hefny M.M., Salih S.A. and El-Basiouny M.S. (1989). Corrosion, 45,574.

Gaur J.N. and Jain B.L. (1978). J. Electrochem. Soc. India, 27, 117.

Huang C. , Zhang W. , and Cao X. (1997). J. App. Electrochem., 27, 695.

Larabi, L., Harek,Y., Traisnel M., Mansri A. (2004). J.Appl.Electrochem., 34, 833. 
Lagrenee M., Mernari B., Bouanis M., Traisnel M., Bentiss F. (2002). Corros. Sci., 49, 2254.

Lebrini M., Lagrenee M., Vezin H., Traisnel M., Bentiss F. (2007). Corros. Sci., 49, 2254.

Manov S., Lamazouere A. M. and Aries L. (1999). J.Appl.Electrochem. 29, 995.

Martinez S.and Stern I. (2002). Appl. Surf. Sci. 199, 83.

Martinez S.and Stern I. (2001). J.Appl.Electrochem., 31, 973.

Mihit M., El-Issami S., Bouklah M., Bazzi L., Hammouti B., Addi E.A., Salghi R., Kertit S. (2006). Appl.Surf.Sci. 252,2389 .

Mohamed, A.k., Bekheit, M.M. and Fouda, A.S. (1991). Bull.Chim.Fr., 128, 331.

Naja M., Penazzi N., Farnia G., and Sandona G. (1993). Electrochim Acta, 38, 1453.

Putilova, I.N., Balezin,S.A.., Barannik, V.P. (1960). Metallic Corrosion Inhibitors, Pergamon Press,, N.Y.31.

Popova, A., Sokolova,E., Raicheva, S. and Chritov, M. ( 2003). Corros.Sci., 45, 33.

Rajappa S.K., Arthoba Naik Y., and Venkatesha T.V. (2001). Bull Electrochem., 17, 489.

Rajendran, S. (2005). J.Electrochem.Soc., 54(2), 61.

Ravindran, Visalakshi and Muralidharan V.S. (1993). Anti-Corros. Methods and Materials, 42, 10.

Salghi R. , Hamouti B. , Aounti A., Berrabah M., and Kertit S. (2000). J. Electrochem. Soc. India, 49 (1), 40.

Selim I.Z. (1998). Bull. Electrochem. 13, 385.

Shanthamma Kampalappa, Rajappa ,Thimmappa V.Venktesha. (2003). Turk J. Chem, 27,189.

Stern M. and Geary A. (1957). J.Electrochem.Soc., 104, 56.

Szlarska-Smialowska, Z., and Mankovwski, J. (1978). Corros.Sci., 18, 953.

Tebbji K., Bouabdellah I., Aouniti A., Hammouti B, Oudda H., Benkaddour M., Ramdani A. (2007). Mater. Lett. 61,799 .

Tsuru T., Haruyama S. , Boshoku G. (1978). J. Japan Soc. Corros. Eng. 27, 573.

Venckatesh, Syed Shabudeen P.S. and Gopal S. (2007). Eur.J. Chem., 4(1), 137.

Yurt, A., Ulutas, S. and Dal, H. (2006). Appl.Surf.Sci., 253, 919.

Table 1. Effect of inhibitors concentrations on the percentage inhibition efficiency (I \%) of zinc in $0.4 \mathrm{M} \mathrm{HCl}$ solution from weight - loss method at $30^{\circ} \mathrm{C}$

\begin{tabular}{|ccccc|}
\hline $\begin{array}{c}\text { Conc. } \\
(\mathrm{M})\end{array}$ & $(1)$ & $(2)$ & $\mathrm{I} \%$ & $(3)$ \\
\hline & \cline { 2 - 5 } & 58.1 & 30.0 & 28.2 \\
$5 \times 10^{-6}$ & 53.4 & 51.2 & 46.2 & 44.4 \\
$5 \times 10^{-6}$ & 61.4 & 58.8 & 56.1 & 55.7 \\
$9 \times 10^{-6}$ & 68.0 & 68.3 & 66.8 & 64.1 \\
$13 \times 10^{-6}$ & 76.0 & 79.4 & 78.6 & 74.1 \\
$17 \times 10^{-6}$ & 80.8 & 84.3 & 82.8 & 77.5 \\
$21 \times 10^{-6}$ & 88.4 & & & \\
\hline
\end{tabular}


Table 2. Number of active sites (1/y), slopes of Langmuir isotherm lines, equilibrium constant of the adsorption process $(\mathrm{K})$ and free energy of adsorption $\left(\Delta \mathrm{G}_{\text {ads }}^{\circ}\right)$ of inhibitors for $\mathrm{Zn}$ in $0.4 \mathrm{M} \mathrm{HCl}$ at $30^{\circ} \mathrm{C}$

\begin{tabular}{|c|c|c|c|c|c|c|}
\hline \multirow[b]{2}{*}{ Inhibitors } & \multicolumn{3}{|c|}{ Langmuir isotherm } & \multicolumn{3}{|c|}{ Kinetic model } \\
\hline & Slope $=y$ & $\begin{array}{c}\mathrm{K} \times 10^{-5} \\
\mathrm{M}^{-1}\end{array}$ & $\begin{array}{c}-\Delta \mathrm{G}^{\circ} \text { ads } \\
(\mathrm{kJ} / \mathrm{mol})\end{array}$ & $1 / \mathrm{y}$ & $\begin{array}{c}\mathrm{K} \times 10^{-5} \\
\mathrm{M}^{-1}\end{array}$ & $\begin{array}{c}-\Delta \mathrm{G}_{\mathrm{ads}}^{\circ} \\
(\mathrm{kJ} / \mathrm{mol})\end{array}$ \\
\hline (1) & 1.039 & 4.07 & 42.7 & 1.751 & 6.7 & 43.9 \\
\hline (2) & 1.093 & 3.01 & 41.9 & 1.782 & 4.0 & 42.6 \\
\hline (3) & 1.099 & 2.08 & 41.0 & 1.889 & 2.5 & 41.2 \\
\hline (4) & 1.122 & 1.64 & 40.4 & 2.111 & 2.1 & 41.0 \\
\hline
\end{tabular}

Table 3. Effect of inhibitors concentrations on the activation energy, activation enthalpy and activation entropy of $\mathrm{Zn}$ dissolution in $0.4 \mathrm{M} \mathrm{HCl}$

\begin{tabular}{|cccccc|}
\hline & Conc., $\mathrm{M}$ & \multicolumn{5}{c|}{ Compounds } \\
\cline { 2 - 6 } & Blank & $(1)$ & $(2)$ & $(3)$ & $(4)$ \\
\cline { 2 - 6 }$\Delta \mathrm{E}^{*}$, & $9 \times 10^{-6}$ & 24.1 & 245.46 & 32.6 & 33.3 \\
$\mathrm{~kJ} / \mathrm{mol}$ & $1.3 \times 10^{-5}$ & 23.1 & 22.9 & 29.5 & 33.1 \\
& $1.7 \times 10^{-5}$ & 20.5 & 23.4 & 28.7 & 32.9 \\
& $2.1 \times 10^{-5}$ & 18.0 & 22.2 & 27.0 & 30.2 \\
\hline & Blank & \multicolumn{2}{c}{33.68} & \\
$\Delta \mathrm{H}^{*}$, & $9 \times 10^{-6}$ & 22.4 & 22.7 & 29.6 & 31.5 \\
$\mathrm{~kJ} / \mathrm{mol}$ & $1.3 \times 10^{-5}$ & 19.9 & 21.7 & 27.9 & 31.5 \\
& $1.7 \times 10^{-5}$ & 16.9 & 21.5 & 27.0 & 30.6 \\
& $2.1 \times 10^{-5}$ & 16.0 & 20.4 & 24.9 & 28.5 \\
\hline & Blank & & 165.41 & & \\
$\mathrm{~J} / \mathrm{mol} / \mathrm{K}$ & $9 \times 10^{-6}$ & 209.3 & 204.7 & 186.3 & 174.9 \\
& $1.3 \times 10^{-5}$ & 226.1 & 209.6 & 190.8 & 184.6 \\
& $1.7 \times 10^{-5}$ & 231.0 & 209.8 & 197.8 & 198.1 \\
& $2.1 \times 10^{-5}$ & 238.3 & 222.1 & 207.6 & 220.4 \\
\hline
\end{tabular}


Table 4. Corrosion parameters of zinc electrode in $0.4 \mathrm{M} \mathrm{HCl}$ solution containing different concentrations of compounds (1-4).

\begin{tabular}{|ccccccccc|}
\hline Comp. & $\begin{array}{c}\text { Conc., } \\
(\mathrm{M})\end{array}$ & $\begin{array}{c}-\mathrm{E}_{\text {corr. }} \\
(\mathrm{V})\end{array}$ & $\begin{array}{c}\mathrm{j}_{\text {corr. }} \\
\left(\mathrm{mA} / \mathrm{cm}^{2}\right)\end{array}$ & $\begin{array}{c}\beta_{\mathrm{c}} \\
(\mathrm{mV} / \mathrm{dec})\end{array}$ & $\begin{array}{c}\beta_{\mathrm{a}} \\
(\mathrm{mV} / \mathrm{dec})\end{array}$ & $\begin{array}{c}\mathrm{R}_{\mathrm{p}} \\
\left(\Omega \mathrm{cm}^{2}\right)\end{array}$ & $\theta$ & $\%$ IE \\
\cline { 2 - 10 } & Blank & 1.015 & 33.09 & 1018 & 700 & 5.44 & - & - \\
& $1 \times 10^{-6}$ & 1.047 & 5.36 & 339 & 309 & 12.28 & 0.838 & 83.8 \\
& $5 \times 10^{-6}$ & 1.033 & 4.86 & 332 & 299 & 14.25 & 0.853 & 85.3 \\
& $9 \times 10^{-6}$ & 1.061 & 4.41 & 358 & 290 & 15.75 & 0.867 & 86.7 \\
& $1.3 \times 10^{-5}$ & 1.057 & 4.15 & 347 & 286 & 15.95 & 0.875 & 87.5 \\
& $1.7 \times 10^{-5}$ & 1.051 & 3.86 & 342 & 277 & 17.23 & 0.883 & 88.3 \\
& $2.1 \times 10^{-5}$ & 1.053 & 2.30 & 299 & 255 & 25.45 & 0.930 & 93.0 \\
\hline \multirow{4}{*}{2} & $1 \times 10-6$ & 1.021 & 7.67 & 537 & 463 & 12.28 & 0.768 & 76.8 \\
& $5 \times 10-6$ & 1.022 & 6.71 & 515 & 374 & 12.93 & 0.797 & 79.7 \\
& $9 \times 10-6$ & 1.015 & 6.27 & 489 & 340 & 14.02 & 0.810 & 81.0 \\
& $1.3 \times 10-5$ & 1.014 & 5.04 & 438 & 324 & 16.05 & 0.848 & 84.8 \\
& $1.7 \times 10-5$ & 1.010 & 4.15 & 450 & 308 & 19.16 & 0.875 & 87.5 \\
& $2.1 \times 10-5$ & 1.030 & 3.61 & 407 & 304 & 20.9 & 0.891 & 89.1 \\
\hline & $1 \times 10-6$ & 1.066 & 8.91 & 543 & 396 & 9.91 & 0.73 & 73.1 \\
& $5 \times 10-6$ & 1.064 & 8.50 & 490 & 388 & 11.07 & 0.743 & 74.3 \\
& $9 \times 10-6$ & 1.056 & 8.31 & 473 & 377 & 13.50 & 0.749 & 74.9 \\
& $1.3 \times 10-5$ & 1.015 & 7.74 & 452 & 349 & 11.05 & 0.766 & 76.6 \\
& $1.7 \times 10-5$ & 1.017 & 7.13 & 428 & 341 & 11.31 & 0.785 & 78.5 \\
& $2.1 \times 10-5$ & 1.052 & 4.05 & 418 & 329 & 21.43 & 0.878 & 87.8 \\
\hline \multirow{4}{*}{4} & $1 \times 10-6$ & 1.071 & 16.53 & 696 & 525 & 7.89 & 0.501 & 50.1 \\
& $5 \times 10-6$ & 1.058 & 11.00 & 556 & 406 & 9.27 & 0.668 & 66.8 \\
& $9 \times 10-6$ & 1.055 & 9.79 & 535 & 384 & 9.92 & 0.704 & 70.4 \\
& $1.3 \times 10-5$ & 1.052 & 9.00 & 510 & 394 & 10.72 & 0.728 & 72.8 \\
& $1.7 \times 10-5$ & 1.053 & 7.62 & 451 & 356 & 11.3 & 0.770 & 77.0 \\
& $2.1 \times 10-5$ & 1.036 & 6.53 & 460 & 345 & 13.11 & 0.803 & 80.3 \\
\hline
\end{tabular}

Table 5. The values of the electrochemical impedance parameters and \% inhibition for zinc in $0.4 \mathrm{M} \mathrm{HCl}$ solution in the absence and presence of different concentrations of compounds (1-4) at $30^{\circ} \mathrm{C}$

\begin{tabular}{|cccccc|}
\hline \multirow{2}{*}{ Compound } & $\begin{array}{c}\text { Conc., } \\
\mathrm{M}\end{array}$ & $\begin{array}{c}\mathrm{C}_{\mathrm{dl}} \\
\mu \mathrm{F} / \mathrm{cm}^{2}\end{array}$ & $\begin{array}{c}\mathrm{R}_{\mathrm{ct}} \\
\Omega \mathrm{cm}^{2}\end{array}$ & $\theta$ & $\%$ IE \\
\hline \multirow{4}{*}{1} & Blank & 115.9 & 0.86 & - & - \\
& $9 \times 10^{-6}$ & 114.2 & 1.05 & 0.18 & 18.38 \\
& $1.3 \times 10^{-5}$ & 78.61 & 1.86 & 0.54 & 53.974 \\
& $1.7 \times 10^{-5}$ & 73.6 & 1.92 & 0.55 & 55.25 \\
& $2.1 \times 10^{-5}$ & 79.36 & 2.21 & 0.613 & 61.29 \\
\hline & $9 \times 10^{-6}$ & 101.1 & 1.462 & 0.41 & 41.38 \\
& $1.3 \times 10^{-5}$ & 93.66 & 1.64 & 0.48 & 47.74 \\
& $1.7 \times 10^{-5}$ & 95.56 & 1.75 & 0.51 & 51.53 \\
& $2.1 \times 10^{-5}$ & 73.5 & 2.153 & 0.60 & 60.20 \\
\hline & $9 \times 10^{-6}$ & 104.1 & 1.23 & 0.30 & 30.38 \\
& $1.3 \times 10^{-5}$ & 92.23 & 1.52 & 0.44 & 43.47 \\
& $1.7 \times 10^{-5}$ & 70.63 & 1.9 & 0.55 & 54.90 \\
4 & $2.1 \times 10^{-5}$ & 66.26 & 2.0 & 0.57 & 57.17 \\
\hline & $9 \times 10^{-6}$ & 104.7 & 1.19 & 0.28 & 27.98 \\
& $1.3 \times 10^{-5}$ & 79.42 & 1.54 & 0.44 & 44.49 \\
& $1.7 \times 10^{-5}$ & 83.33 & 1.68 & 0.49 & 49.11 \\
& $2.1 \times 10^{-5}$ & 64.78 & 1.95 & 0.56 & 56.03 \\
\hline
\end{tabular}


Table 6. Electrochemical kinetic parameters obtained by EFM for zinc in $0.4 \mathrm{M} \mathrm{HCl}$ solution, in the absence and presence of different concentrations of compounds (1-4) at $30^{\circ} \mathrm{C}$

\begin{tabular}{|ccccccccc|}
\hline Comp. & $\begin{array}{c}\text { Conc., } \\
\mathrm{M}\end{array}$ & $\begin{array}{c}\mathrm{j}_{\text {corr }} \\
\left(\mathrm{mA} / \mathrm{cm}^{2}\right)\end{array}$ & $\begin{array}{c}\beta_{1} \\
(\mathrm{mV} / \mathrm{dec})\end{array}$ & $\begin{array}{c}\beta_{2} \\
(\mathrm{mV} / \mathrm{dec})\end{array}$ & $\begin{array}{c}\text { Causality } \\
\text { Factor }(2)\end{array}$ & $\begin{array}{c}\text { Causality } \\
\text { Factor }(3)\end{array}$ & $\theta$ & IE\% \\
\hline \multirow{4}{*}{1} & Blank & 2.14 & 0.43 & 0.49 & 1.8 & 2.86 & - & - \\
& $9 \times 10^{-6}$ & 1.2 & 0.35 & 0.37 & 2.12 & 3.09 & 0.44 & 43.8 \\
& $1.3 \times 10^{-5}$ & 1.16 & 0.34 & 0.35 & 2.21 & 2.74 & 0.46 & 45.9 \\
& $1.7 \times 10^{-5}$ & 1.08 & 0.31 & 0.39 & 2.15 & 3.17 & 0.50 & 49.5 \\
& $2.1 \times 10^{-5}$ & 1.01 & 0.26 & 0.30 & 2.13 & 3.14 & 0.53 & 52.9 \\
\hline \multirow{4}{*}{2} & $9 \times 10^{-6}$ & 1.21 & 0.36 & 0.37 & 2.01 & 3.04 & 0.43 & 43.3 \\
& $1.3 \times 10^{-5}$ & 1.16 & 0.34 & 0.35 & 2.23 & 2.90 & 0.46 & 45.8 \\
& $1.7 \times 10^{-5}$ & 1.11 & 0.31 & 0.35 & 1.82 & 2.67 & 0.48 & 48.2 \\
& $2.1 \times 10^{-5}$ & 1.07 & 0.30 & 0.31 & 1.62 & 2.77 & 0.50 & 50.1 \\
\hline \multirow{4}{*}{3} & $9 \times 10^{-6}$ & 1.2 & 0.36 & 0.39 & 2.12 & 3.02 & 0.43 & 42.6 \\
& $1.3 \times 10^{-5}$ & 1.2 & 0.34 & 0.36 & 2.31 & 3.13 & 0.45 & 45.5 \\
& $1.7 \times 10^{-5}$ & 1.2 & 0.31 & 0.41 & 1.79 & 3.29 & 0.46 & 46.0 \\
& $2.1 \times 10^{-5}$ & 1.1 & 0.30 & 0.34 & 1.84 & 2.87 & 0.49 & 49.1 \\
\hline \multirow{4}{*}{4} & $9 \times 10^{-6}$ & 1.3 & 0.39 & 0.41 & 1.86 & 2.65 & 0.40 & 39.6 \\
& $1.3 \times 10^{-5}$ & 1.2 & 0.30 & 0.38 & 2.12 & 2.73 & 0.45 & 44.6 \\
& $1.7 \times 10^{-5}$ & 1.2 & 0.34 & 0.36 & 2.23 & 3.19 & 0.45 & 45.4 \\
& $2.1 \times 10^{-5}$ & 1.1 & 0.31 & 0.33 & 1.86 & 2.86 & 0.49 & 48.8 \\
\hline
\end{tabular}

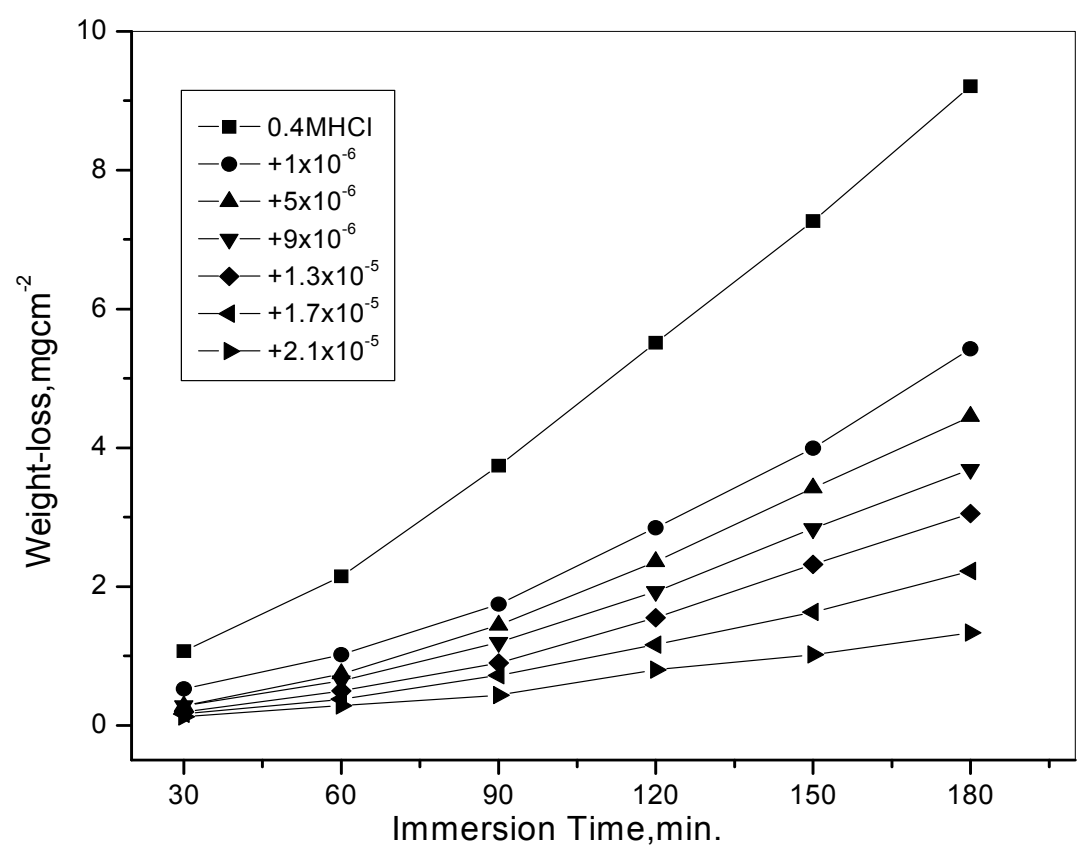

Fig. (1): Weight-loss versus immersion time for zinc immersed in $0.4 \mathrm{M} \mathrm{HCl}$ in the absence and presence different concentrations of compound(1) at $30^{\circ} \mathrm{C}$. 


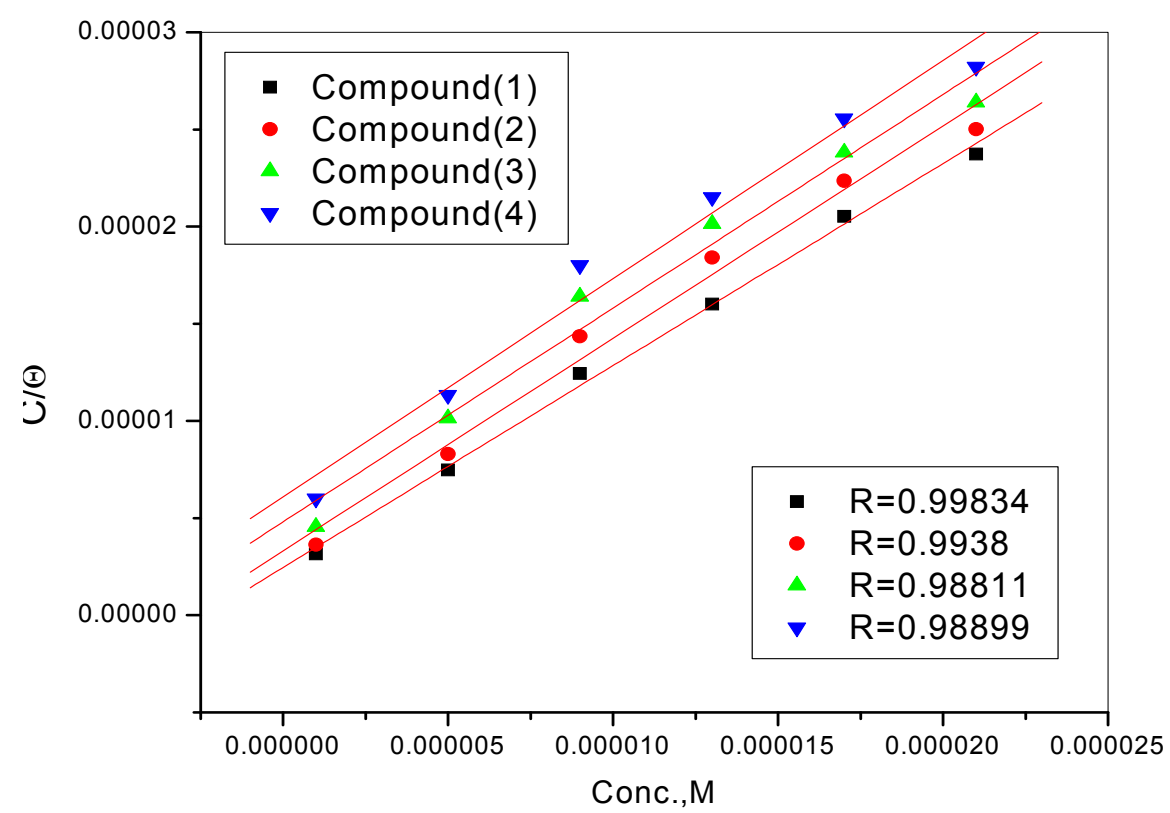

Figure 2. Langmuir adsorption isotherm plotted as $(\mathrm{C} / \theta)$ vs. Conc. of inhibitors for the corrosion of $\mathrm{Zn}$ in $0.4 \mathrm{M} \mathrm{HCl}$ solution at $30^{\circ} \mathrm{C}$.

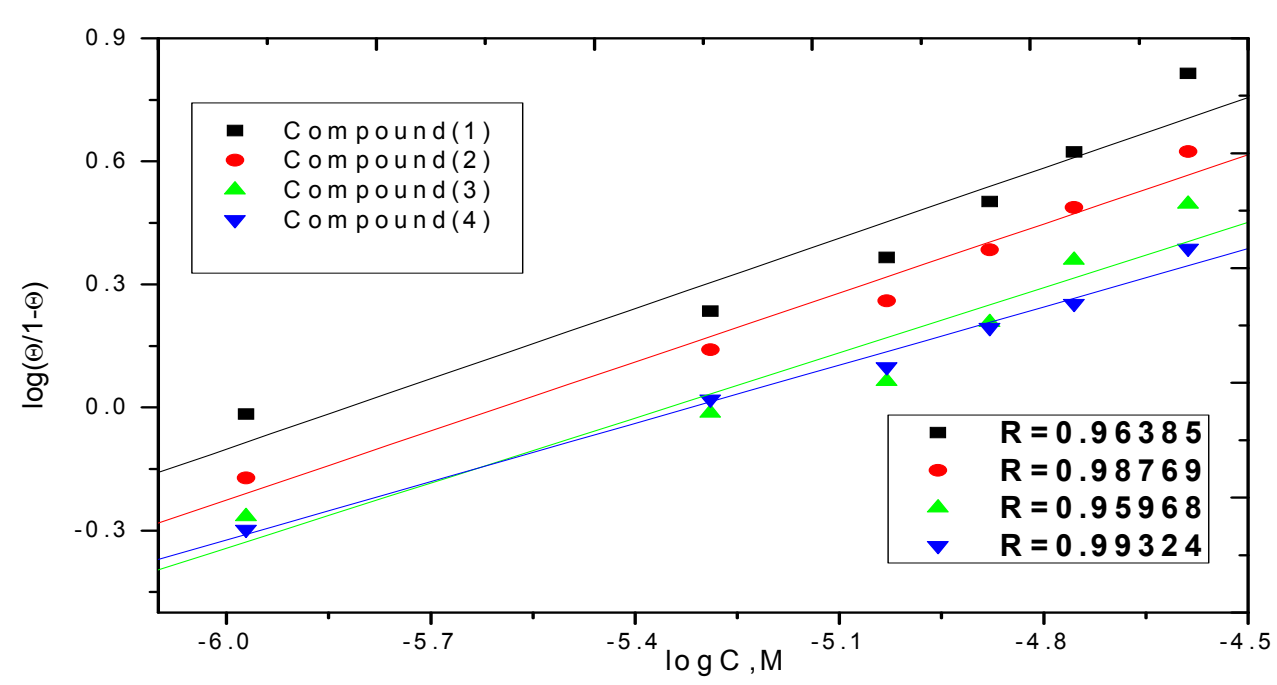

Fig.(3): El-Awady model plotted as log $(\Theta / 1-\Theta)$ vs.log C of inhibitors for corrosion of $\mathrm{Zn}$ in $0.4 \mathrm{M} \mathrm{HCl}$ at $30^{\circ} \mathrm{C}$. 


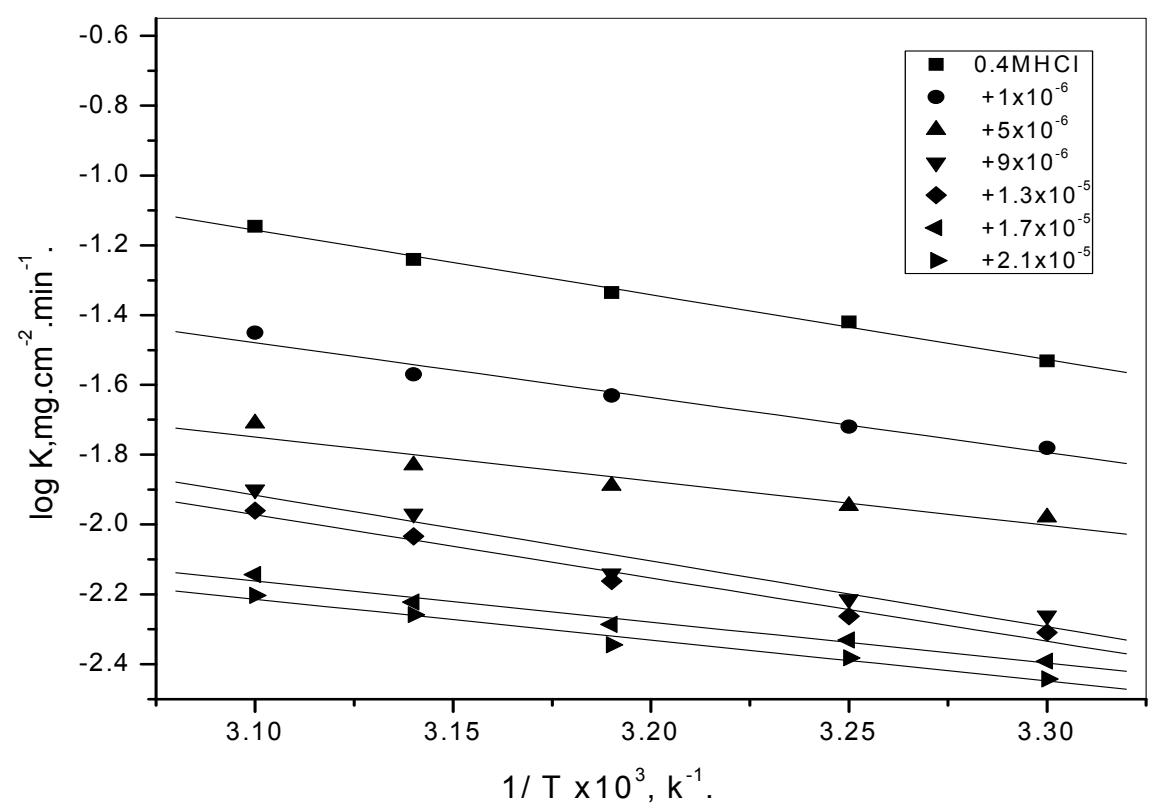

Fig.(4) Arrhenius plots (logk vs.1/T) for $\mathrm{Zn}$ in $0.4 \mathrm{M} \mathrm{HCl}$ in the absence and in presence of different concentrations of compound(1).

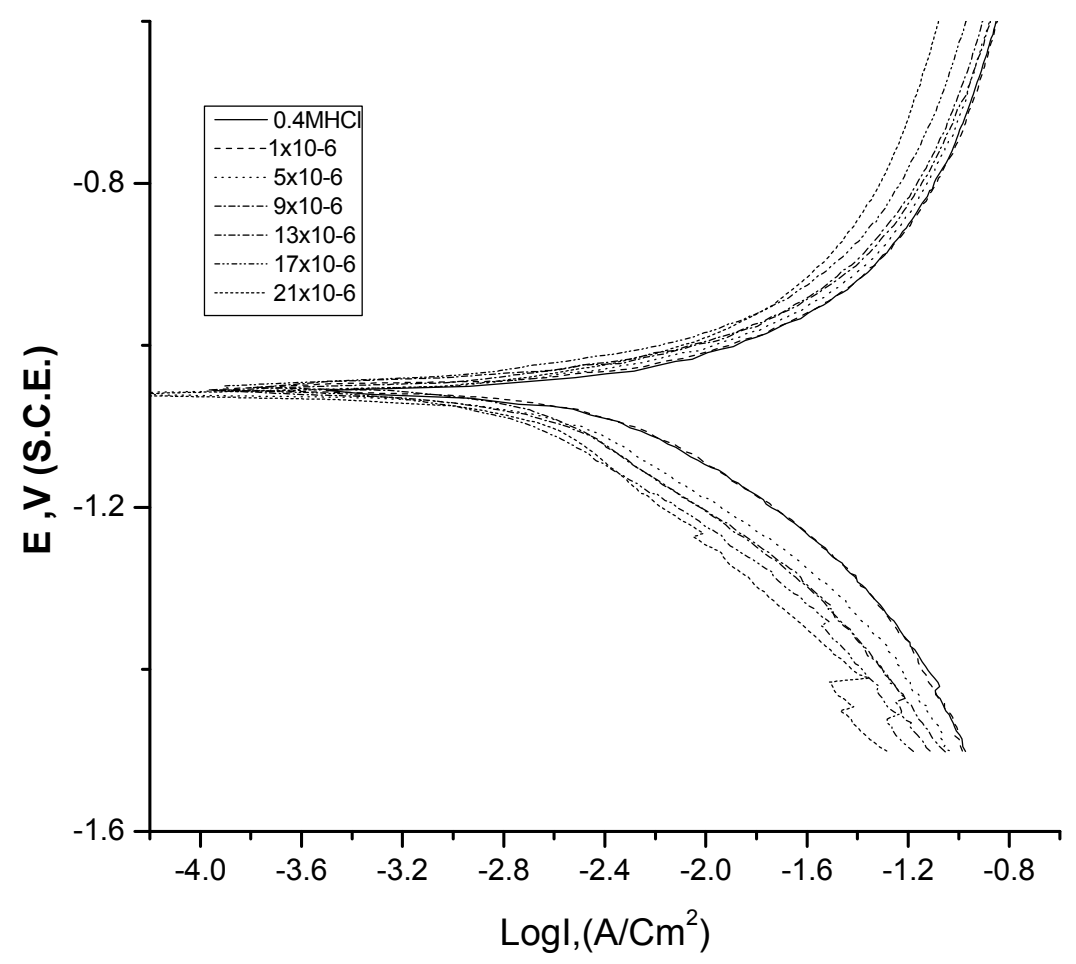

Fig.(5):The potentiodynamic Polarization curves for zinc in $0.4 \mathrm{M} \mathrm{HCl}$ solution in the absence and presence of different concentrations of compound (1) at $30^{\circ} \mathrm{C}$. 


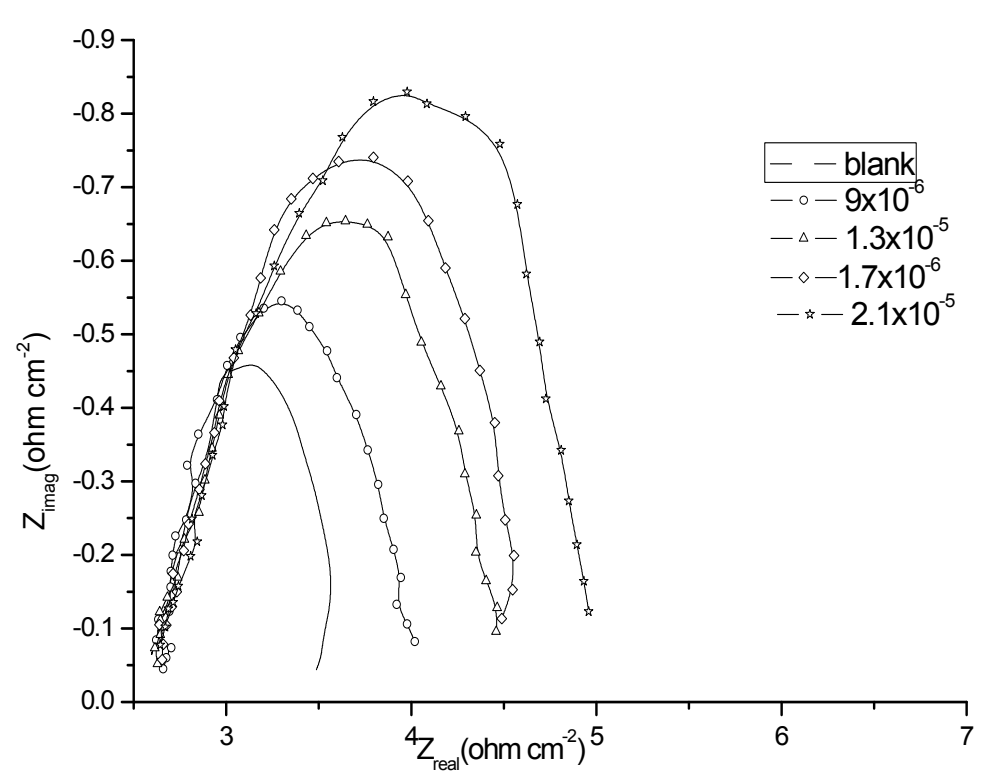

Fig.(6): Nyquist plots for $\mathrm{Zn}$ in $0.4 \mathrm{M} \mathrm{HCl}$ solution in the absence and presence of different concentrations of compound(1) at $30^{\circ} \mathrm{C}$.

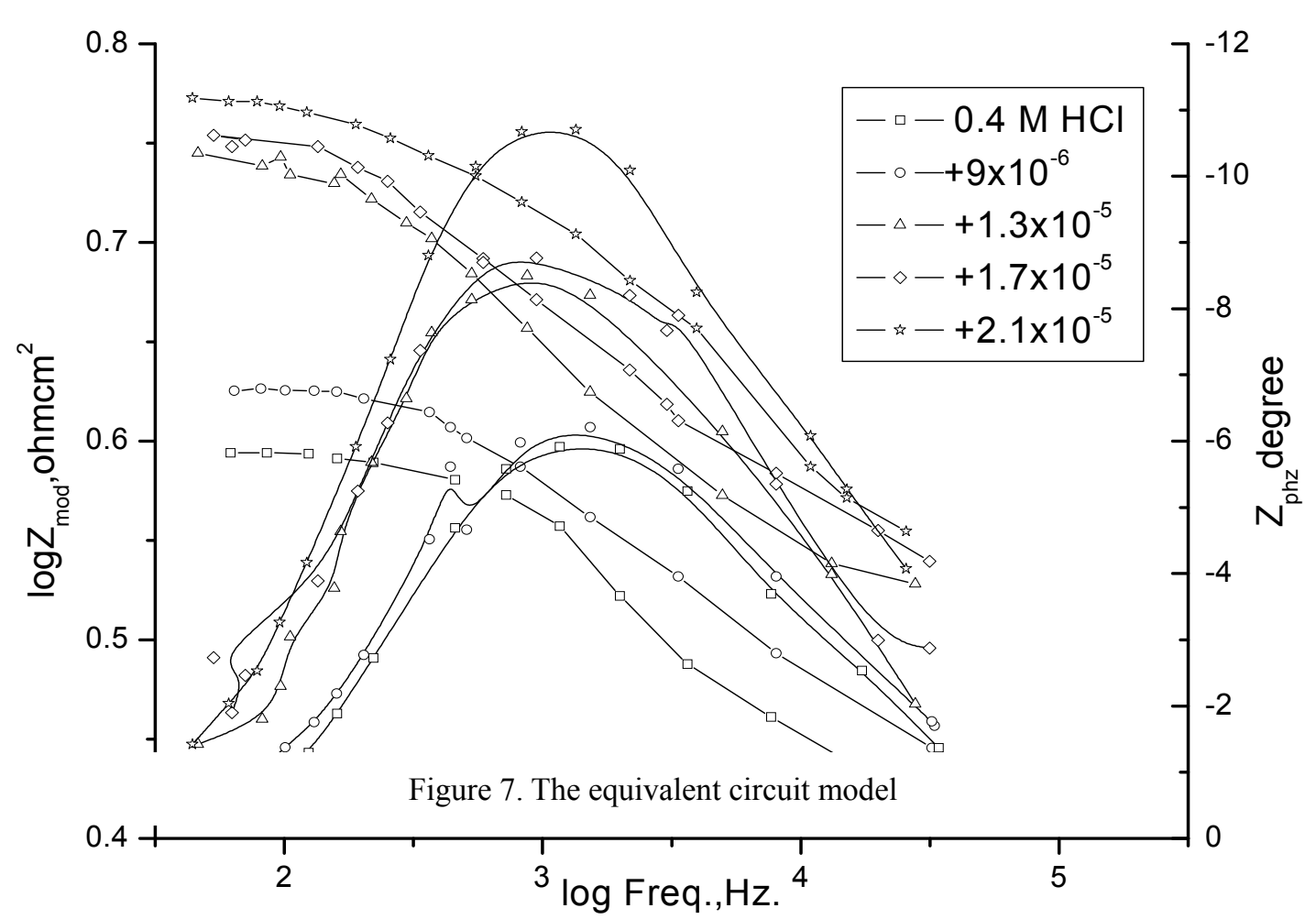

Fig. 7 )The Bode plots for the corrosion of $\mathrm{Zn}$ in $0.4 \mathrm{M} \mathrm{HCl}$ in the absence and presence of different concentrations of inhibitor(1)at $30^{\circ} \mathrm{C}$. 


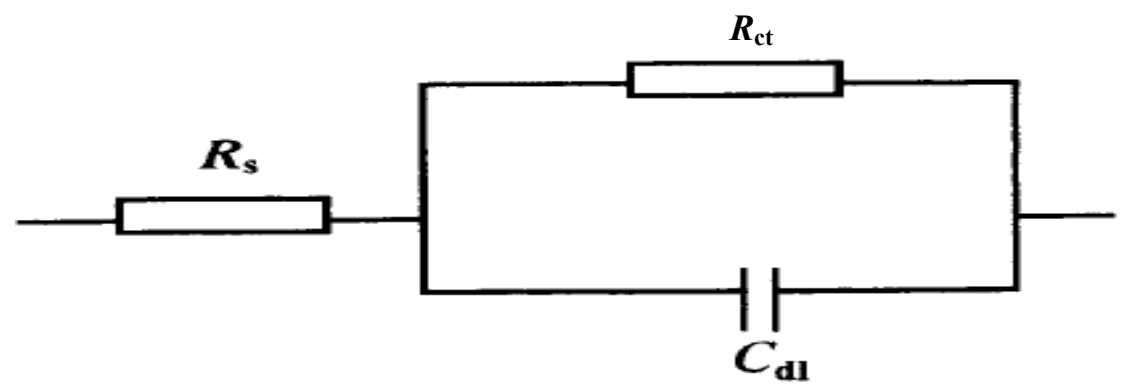

Figure 8. The equivalent circuit model

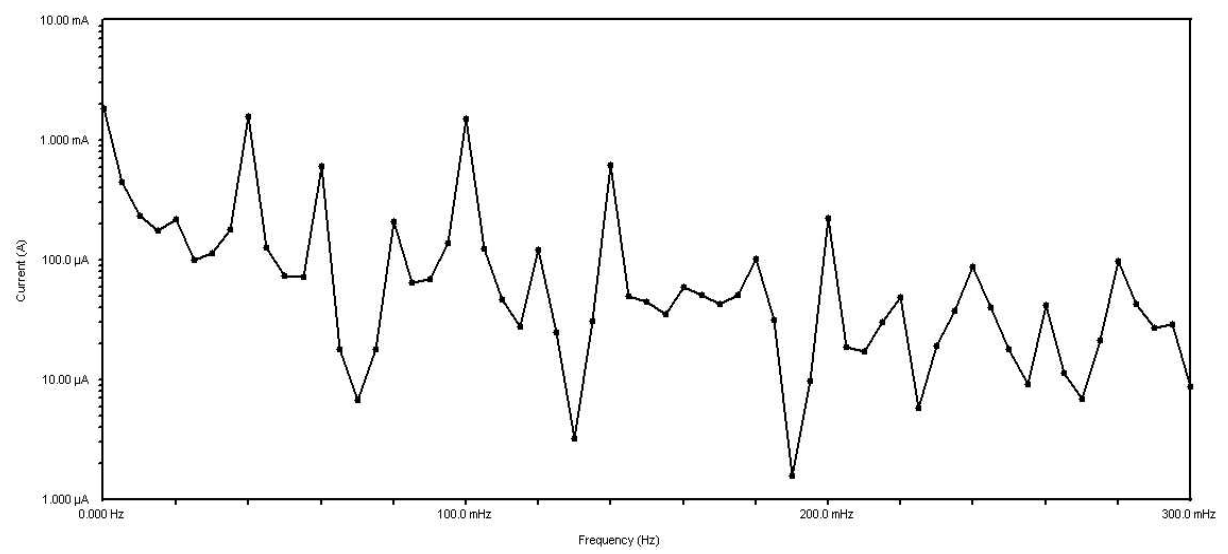

Figure 9. Inter modulation spectrum for zinc metal in $0.4 \mathrm{M} \mathrm{HCl}$ (Blank) at $30^{\circ} \mathrm{C}$

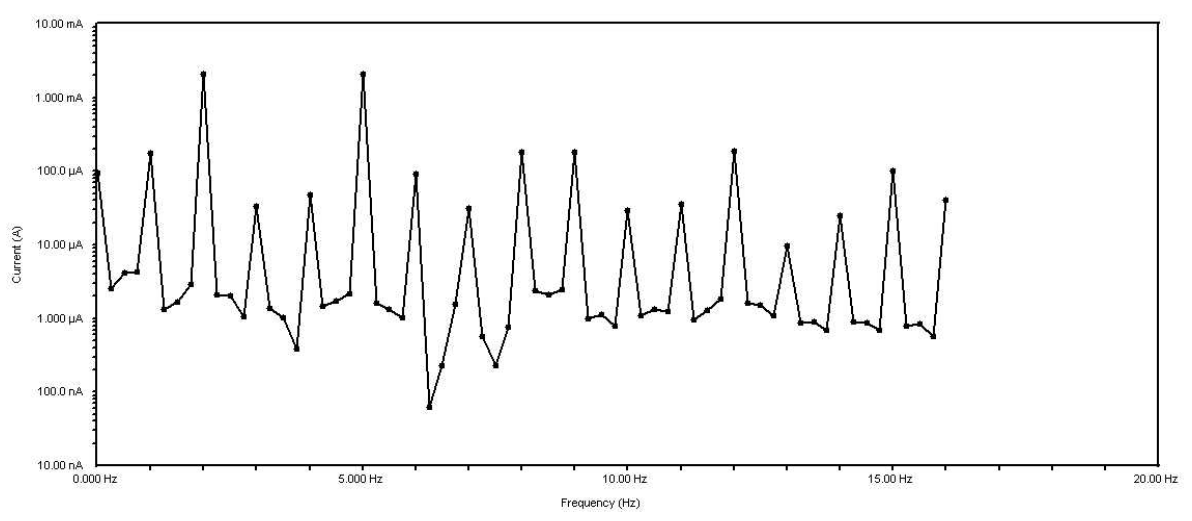

Figure 10. Inter modulation spectrum for zinc metal in $0.4 \mathrm{M} \mathrm{HCl}$ in presence of $9 \times 10^{-6} \mathrm{M}$ Inhibitor (1) at $30^{\circ} \mathrm{C}$

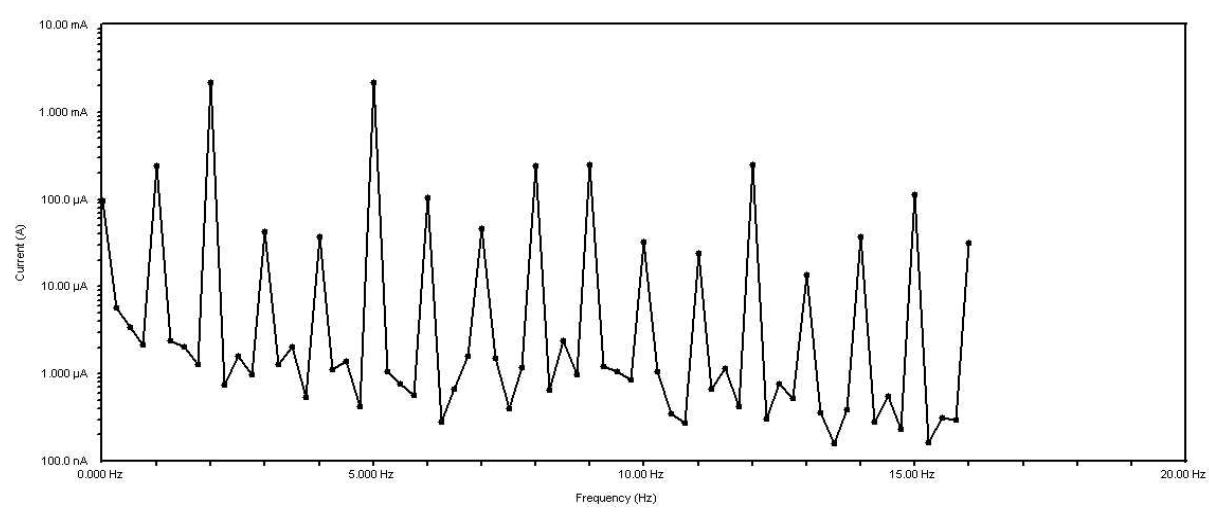

Figure 11. Inter modulation spectrum for zinc metal in $0.4 \mathrm{M} \mathrm{HCl}$ in presence of $13 \times 10^{-6} \mathrm{M}$ inhibitor (1) at $30^{\circ} \mathrm{C}$ 


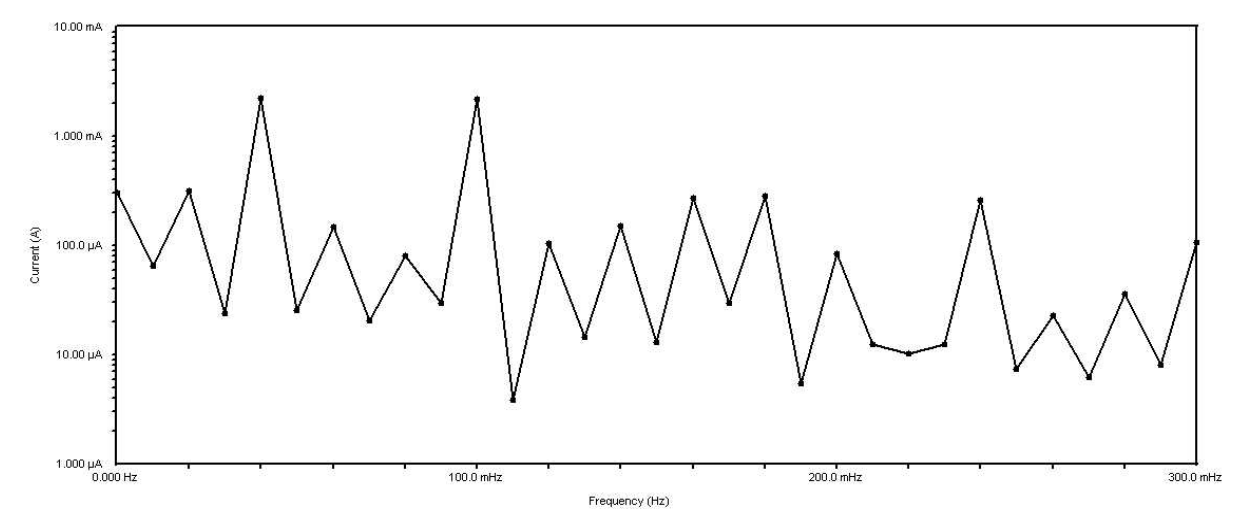

Figure 12. Inter modulation spectrum for zinc metal in $0.4 \mathrm{M} \mathrm{HCl}$ solution in presence of $17 \times 10^{-5} \mathrm{M}$ inhibitor (1) at $30^{\circ} \mathrm{C}$.

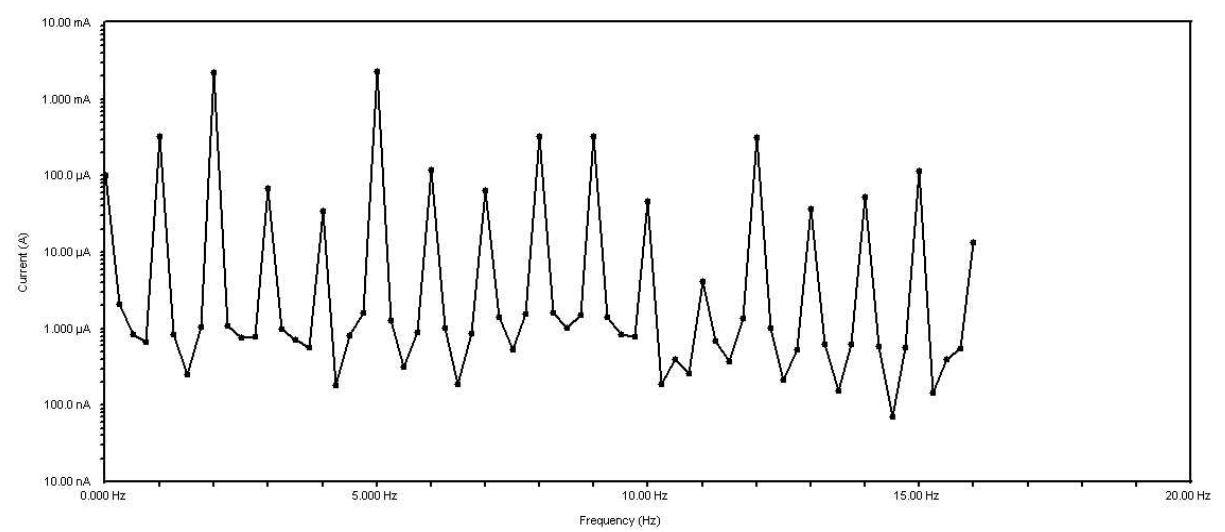

Figure 13. Inter modulation Spectrum for Zinc metal in $0.4 \mathrm{M} \mathrm{HCl}$ in presence of $21 \times 10^{-5} \mathrm{M}$ inhibitor (1) at $30^{\circ} \mathrm{C}$ 